\title{
Experimental infection with equid herpesvirus 3 in seronegative and seropositive mares
}

\author{
M. Barrandeguy ${ }^{\mathrm{a}, *}$, A. Vissani ${ }^{\mathrm{a}}$, C. Olguin ${ }^{\mathrm{a}}$, G. Barbara ${ }^{\mathrm{b}}$, H. Valenzuela $^{\mathrm{c}}$, \\ L. Becerra ${ }^{a}$, M. Tordoya ${ }^{a}$, S. Miño ${ }^{a}, E^{2}$ Thiry ${ }^{d}$ \\ a Instituto de Virología, CICVyA, INTA-Castelar, CC25, 1712 Castelar, Buenos Aires, Argentina \\ ${ }^{\mathrm{b}}$ Private Veterinarian Equine Reproduction Practitioner, Rosario, Santa Fe, Argentina \\ ${ }^{\mathrm{c}}$ Private Veterinarian Equine Reproduction Practitioner, Luján, Buenos Aires, Argentina \\ ${ }^{\mathrm{d}}$ Veterinary Virology and Animal Viral Diseases, Department of Infectious and Parasitic Diseases, Faculty of Veterinary Medicine, University of Liege, B-4000 Liege, \\ Belgium
}

\section{A R T I C L E I N F O}

\section{Article history:}

Received 16 March 2012

Received in revised form 11 June 2012

Accepted 19 June 2012

\section{Keywords:}

Equine coital exanthema

Equid herpesvirus 3

Equine

Experimental infection

\begin{abstract}
A B S T R A C T
Equine coital exanthema (ECE), caused by equid herpesvirus 3 (EHV-3), has been recognized as an economically significant venereal disease for years. However, no infection models on the natural host have been established. In order to set up an experimental infection protocol, seronegative and seropositive mares were topically inoculated in the perineal region with $4 \times 10^{6} \mathrm{TCID}_{50} / \mathrm{ml}$ of EHV-3. Clinical signs were then evaluated by means of a designed scoring system, and body temperature was recorded daily. Virological, and serological studies were also performed. Typical ECE lesions, with clinical scores of 90,92,160 and 172, were observed in the four seronegative animals. Only mild ECE lesions were observed in the two seropositive mares, being the clinical scores 53 and 41. Both groups of mares shed the virus, but the duration of virus shedding was shorter and its intensity was lower in seropositive mares than in seronegative ones. Moreover, EHV-3 antibody response was detected in both seronegative and seropositive mares after experimental infection and re-infection, being more moderate in seropositive ones.

As a conclusion, EHV-3 infection of mares was experimentally achieved in a reproducible manner. The typical lesions of ECE were observed after topical EHV-3 infection in seronegative mares, in association with virus excretion and neutralizing antibody kinetics.
\end{abstract}

(c) 2012 Elsevier B.V. All rights reserved.

\section{Introduction}

Equine coital exanthema (ECE), caused by equid herpesvirus 3 (EHV-3), is an acute, venereal disease characterized by the formation of papules, vesicles, pustules and ulcers on the vaginal and vestibular mucosa as well as on the skin of the penis, prepuce and perineal region (Allen and Umphenour, 2004). The disease has been described in most horse breeding populations worldwide,

\footnotetext{
* Corresponding author. Tel.: +54114621 9050; fax: +54 1146219050. E-mail address: mbarrandeguy@cnia.inta.gov.ar (M. Barrandeguy).
}

and has been proved the cause of considerable economic impact (Barrandeguy and Thiry, 2012; Tibary and Fite, 2007). EHV-3 is primarily transmitted through coitus, even though there are also strong evidences of non-coital, iatrogenic spreading by virus-contaminated objects (Allen and Umphenour, 2004; Blanchard et al., 1992; Barrandeguy et al., 2010a,b). The EHV-3 state of latency, with periodic EHV-3 reactivation and re-excretion, as well as the subclinical infection in mares at the age of breeding have been recently demonstrated (Barrandeguy et al., 2008, 2010c). Treatment of the disease is generally limited to sexual rest until the lesions have healed, to prevent further spread of the infection. Antiviral treatments, 
vaccination or other alternative treatments to prevent and control ECE remain largely unexplored (Barrandeguy and Thiry, 2012).

Despite the fact that experimental transmission of ECE from infected mares to stallions by coitus and experimental reproduction of the clinical disease with material extracted from lesions had been previously successfully achieved (Burki et al., 1974; Girard et al., 1968; Monteverde et al., 1960; Krogsrud and Onstad, 1971), an experimental reproduction model of ECE, based on inoculation with titrated low cell-passaged virus, was still not available.

The aim of the present work was to develop a protocol of experimental EHV-3 infection in horses capable of reproducing the lesions observed during the field outbreaks of ECE, and to investigate the virus shedding and antibody response patterns in experimental conditions, both in seronegative (naive) and in seropositive (previously infected and latently infected) mares.

\section{Materials and methods}

\subsection{Viruses}

For the first experimental infection, EHV-3 strain E/ 9283/07 isolated from lesions of a polo mare, infected during an outbreak of ECE in an embryo transfer facility (Barrandeguy et al., 2008), was used as inoculum. For the second experimental infection, EHV-3 strain E/1333/07, isolated from lesions on the penis of an affected thoroughbred stallion, was used as inoculum (Barrandeguy, unpublished data).

Before the final preparation of the experimental infection inocula, both EHV-3 strains were plaque-purified thrice on an equine dermis cell line (ATCC number CCL-57) and passed twice in the same cell culture. The inocula were titrated, aliquoted and kept at $-70{ }^{\circ} \mathrm{C}$ until use. The virus titre was $10^{6.5} \mathrm{TCID}_{50} / \mathrm{ml}$ for the strain $\mathrm{E} / 9283 / 07$ (first experimental infection) and $10^{6.66} \mathrm{TCID}_{50} / \mathrm{ml}$ for the strain E/1333/07 (second experimental infection). These two strains are genetically distinguishable: the partial sequence of the gG gene revealed three base substitutions at positions 904, 1103 and 1264, and are therefore referred to as strain E/9283/07 CAG genotype and strain E/1333/07 ACT genotype (Barrandeguy, 2010).

\subsection{Animals}

\subsubsection{First experimental infection}

Two EHV-3 seronegative mares, G ("gateada”) and R ("ruana"), of an estimated age of 8 and 5 years respectively, were used. The age of the mares was estimated by the presence or absence of permanent teeth and the agedrelated changes in the incisors. The animals were kept in isolation from other animals during the experiment.

\subsubsection{Second experimental infection}

Previously infected (seven months before) mares $\mathrm{R}$ and G and two new EHV-3 seronegative mares, A ("alazana") and $\mathrm{M}$ ("malacara"), were used. The estimated age of $\mathrm{M}$ and
A was 10 and 7 years old respectively. At the beginning of the experiment, mare $\mathrm{M}$ was 10 -month pregnant.

The mares were always managed as two independent groups (seronegative and seropositive). Each group was isolated from one another, as well as from other horses, both before and during the experiment.

Veterinarians specialized in equine practice were in charge of the care, clinical examination and sampling of the animals.

\subsection{Experimental design}

The time frame between the first and second experimental infections was of seven months. During this period of time, mares $\mathrm{G}$ and $\mathrm{R}$ remained isolated from any other horses. Throughout the experiments the animals were kept and treated in accordance with the international standards regarding animal welfare (Anon., 1985), and the experimental infection protocols were approved by the institutional animal care and use committee (Anon., 2007).

The inoculum $(4 \mathrm{ml})$ was topically inoculated in the vagina, on the vulva and on the perineal skin surrounding the vulvar labia, using a swab.

A back titration of the inocula was carried out after the experimental infection challenge.

\subsection{Clinical monitoring}

The animals were monitored by a veterinarian every morning. Body temperature and general clinical signs were recorded, and the genital and perineal skin and mucosa were thoroughly observed. A digital camera was used to record the evolution of the lesions. In addition, a clinical scoring system, by which a score was attributed to each observed lesion and/or clinical sign, was used to quantify the severity of the disease. The parameters considered were the presence or absence of congestion/tumefaction, vulvar discharge, pain at the moment of inspection, characteristics of the lesions (type, size, and number), and secondary bacterial infection or myiasis. The daily score of an individual mare was defined as the sum of the scores of all clinical signs and lesions observed in a day. A total clinical score was calculated for each animal at the end of the experiments (Table 1 ).

\subsection{Clinical samples}

Perineal vaginal swabs (PVS) for virus detection and titration were daily collected by roughly rubbing the perineal/vaginal area with an "in-house made" sterile swab. After sampling, the clinical material obtained was poured into $5 \mathrm{ml}$ of viral transport medium supplemented with $5 \%$ foetal calf serum (Heuschele and Castro, 1992), and immediately transported in ice to the virology laboratory.

Unclotted blood was also daily collected using tubes containing EDTA for routine haematology tests. Blood for serum was collected once a week (every Tuesday, for 2 months). The PVS and serum samples were stored at $-70{ }^{\circ} \mathrm{C}$ and $-20^{\circ} \mathrm{C}$ respectively, pending laboratory studies. 
Table 1

Clinical scoring system used to quantify the severity of lesions.

\begin{tabular}{|c|c|c|c|c|c|}
\hline Score & 0 & 1 & 2 & 3 & 4 \\
\hline Tumefaction & None & Present & - & - & - \\
\hline Discharge & None & Serous & Mucous & Purulent & - \\
\hline Pain & None & Present & - & - & \\
\hline \multicolumn{6}{|l|}{ Lesion } \\
\hline Type & None & Papule & Vesicle & Pustula & Erosion/ulcers \\
\hline Size & None & Small (up to $1 \mathrm{~cm}$ ) & Large (more than $1 \mathrm{~cm}$ ) & - & - \\
\hline Number & None & Up to 4 & More than 4 & - & - \\
\hline Others & None & Secondary bacterial infection/myiasis & - & - & - \\
\hline
\end{tabular}

Note: In the presence of scabs as a consequence of the healing process, in all lesions a score of 0 was attributed.

\subsection{EHV-3 detection and measurement of virus excretion by quantitative real time $P C R$}

DNA was obtained from PVS using a commercial DNA extraction kit according to the manufacturer's instructions. To detect and quantify EHV-3, an adapted quantitative real time PCR assay, targeting a region of the EHV-3 gG gene as shown by Seki et al. (2004), was carried out (Barrandeguy et al., 2008). Quantification of EHV-3 in the PVS was calculated by generating a standard curve with log dilutions of the reference strain containing $10^{6.50} \mathrm{TCID}_{50} /$ $\mathrm{ml}$ and expressed as $\mathrm{TCID}_{50}$ equivalents.

\subsection{Characterization of the excreted virus by DNA sequencing}

The partial-length glycoprotein $\mathrm{G}(\mathrm{gG})$ gene, from nucleotides 802 to 1298 , was amplified by PCR (Dynon et al., 2001) from DNA extracted from EHV-3 positive PVS from each mare, in both experiments, and unpurified PCR products were sequenced (Unidad de Genómica, Instituto de Biotecnología, CICVyA, INTA-Castelar). The obtained nucleotide sequence data were assembled and aligned using the BioEdit Sequence Alignment Editor V7.0.5 program (Hall, 1999). The obtained sequences were compared with the sequence of EHV-3 strains used as inocula in both experiments.

\subsection{Serum neutralization test}

Antibodies against EHV-3 in blood serum samples were detected by the serum neutralization test, as previously described (Barrandeguy et al., 2008). Neutralizing antibody titres were expressed as the $\log _{10}$ of the reciprocal of the highest dilution that completely inhibited the EHV-3 cytopathic effect.

\section{Results}

The back titration of the challenge virus revealed that the titre did not suffer a significant change after the experimental infections, being $10^{6.00} \mathrm{TCID}_{50} / \mathrm{ml}$ for the strain E/9283/07 (first experimental infection) and $10^{6.33} \mathrm{TCID}_{50} / \mathrm{ml}$ for the strain $\mathrm{E} / 1333 / 07$ (second experimental infection).

Mares showed neither hyperthermia nor systemic clinical signs, and the haematological pattern remained normal throughout both experiments.
The typical ECE lesions (vesicles, pustules, erosions and ulcers, of different types, sizes and numbers) were observed in all of the mares (Fig. 1).

The daily and total clinical scores for each mare are shown in Tables 2 and 3, for the first and second experiment respectively. The total clinical scores were 172 and 90 for the two seronegative mares included in the first experiment (Table 2). The total clinical scores obtained during the second experiment were 160 and 92 for the seronegative mares, and 53 and 41 for the seropositive mares (Table 3 ).

Virus shedding was detected by quantitative real time PCR in all mares. The duration and intensity of virus shedding for mares $R$ and $G$ in the first experiment and for mares $A, M, R$ and $G$ in the second experiment are shown in Fig. 2a and $b$ respectively. Excretion started between 1 and 2 days post infection in the seronegative mares, and 4 days post infection in the seropositive ones; at peak, virus excretion was as high as $10^{5.50}$ and $10^{4.00} \mathrm{TCID}_{50} / \mathrm{ml}$ equivalents in the seronegative and seropositive mares respectively. Viral excretion lasted 12 days in mare $R$ and 16 in mare $G$ ( 1 st experiment), and 20 days in mare $A$ and 12 in mare $M$ (2nd experiment), while it lasted 10 days in mare $R$ and 8 days in mare $G$ during the second experiment (both $R$ and $G$ were seropositive mares).

By analyzing nucleotide sequence alignments, it was determined that the EHV-3 shed during the first experimental infection by mares $G$ and $R$, belongs to $C A G$ genotype and the EHV-3 shed by mares $G, R, A$ and $M$ in the second experimental infection belongs to ACT genotype (Fig. 3). These results confirm that, in both experimental infections, the shed virus was identical to the challenging virus.

Antibody response, as measured by serum neutralization test, was detected after infection in all the mares in both experiments, being the increase in antibody titre more evident in the seronegative than in seropositive mares (Fig. 4a and b). In the seronegative mares, neutralizing antibodies were detectable 7 days after experimental infection and remained between 2.1 and 2.7 ( $\log _{10}$ reciprocal of serum dilution) until the end of the study ( 2 months). Regarding the seropositive mares, the antibody titre increased from 1.5 to 2.7 ( $\log _{10}$ reciprocal of serum dilution) in one of them and from 2.1 to $2.7\left(\log _{10}\right.$ reciprocal of serum dilution) in the other one, 7 days post infection. 
(a)
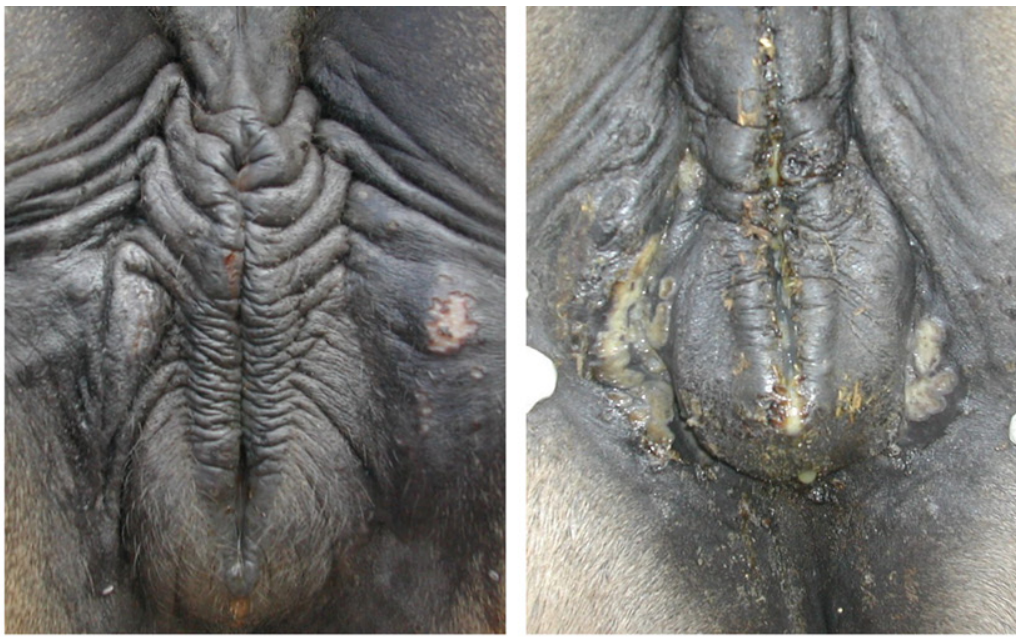

(b)

(c)
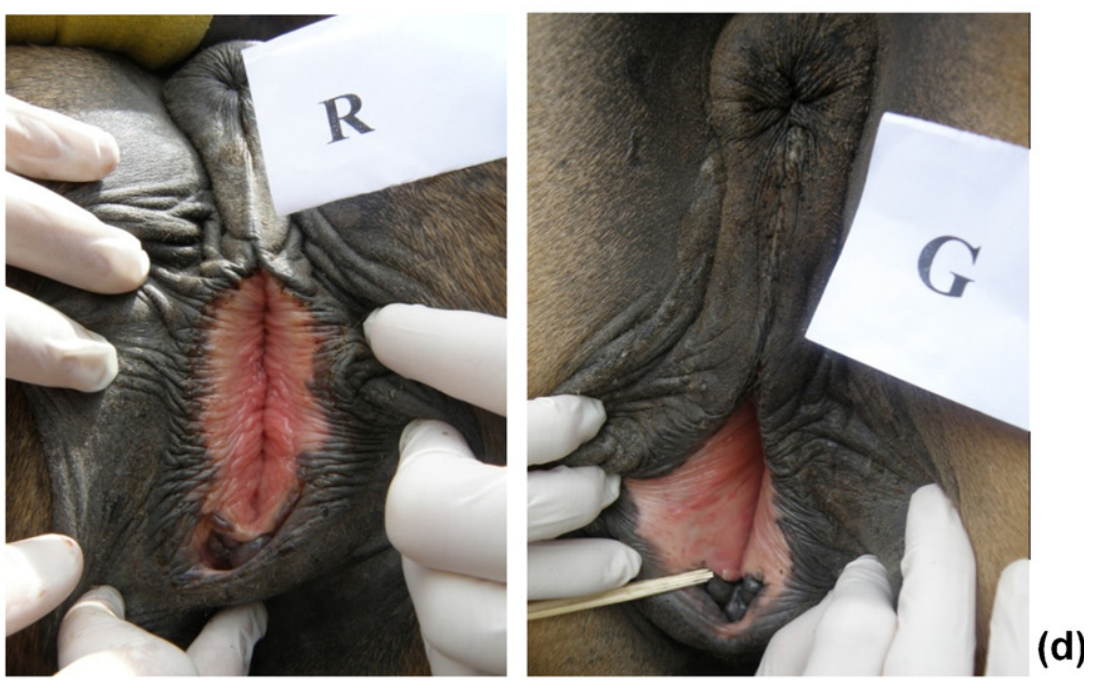

(e)
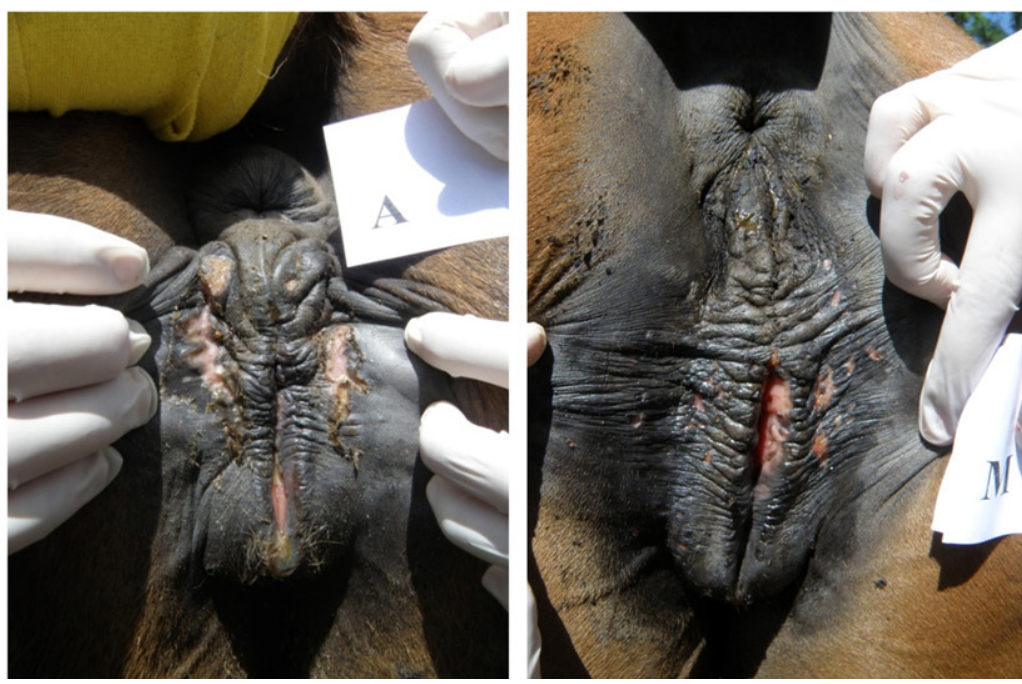

(f)

Fig. 1. Lesions in the vulva and perineal skin observed 8 days post EHV-3 experimental challenge: (a) mare R (1st experiment); (b) mare G (1st experiment); (c) mare R (2nd experiment); (d) mare G (2nd experiment); (e) mare A (2nd experiment); (f) mare M (2nd experiment). 
Table 2

Clinical scores applied to EHV-3 induced lesions observed in mares R and G (primary infection) during the 1st experiment.

\begin{tabular}{|c|c|c|c|c|c|c|c|c|c|c|c|c|c|c|c|c|c|c|c|c|}
\hline \multirow[t]{2}{*}{ Mares } & \multicolumn{20}{|c|}{ Days post-infection } \\
\hline & 0 & 1 & 2 & 3 & 4 & 5 & 6 & 7 & 8 & 9 & 10 & 11 & 12 & 13 & 14 & 15 & 16 & 17 & 18 & Total \\
\hline \multicolumn{21}{|c|}{ Tumefaction } \\
\hline $\mathrm{R}$ & 0 & 0 & 0 & 1 & 1 & 1 & 1 & 1 & 1 & 1 & 1 & 1 & 1 & 1 & 0 & 0 & 0 & 0 & 0 & 11 \\
\hline G & 0 & 0 & 1 & 1 & 1 & 1 & 1 & 1 & 1 & 1 & 1 & 1 & 1 & 1 & 0 & 0 & 0 & 0 & 0 & 12 \\
\hline \multicolumn{21}{|c|}{ Discharge } \\
\hline R & 0 & 0 & 0 & 1 & 0 & 0 & 0 & 0 & 0 & 0 & 0 & 0 & 0 & 0 & 0 & 0 & 0 & 0 & 0 & 1 \\
\hline G & 0 & 0 & 0 & 1 & 2 & 2 & 2 & 2 & 3 & 3 & 3 & 3 & 2 & 1 & 0 & 0 & 0 & 0 & 0 & 24 \\
\hline $\mathrm{R}$ & 0 & 0 & 0 & 1 & 1 & 1 & 1 & 1 & 1 & 1 & 0 & 0 & 0 & 0 & 0 & 0 & 0 & 0 & 0 & 7 \\
\hline G & 0 & 0 & 0 & 1 & 1 & 1 & 1 & 1 & 1 & 1 & 1 & 1 & 1 & 0 & 0 & 0 & 0 & 0 & 0 & 10 \\
\hline \multicolumn{21}{|c|}{ Lesion type } \\
\hline $\mathrm{R}$ & 0 & 2 & 0 & 1 & 2 & 3 & 4 & 4 & 4 & 4 & 4 & 4 & 4 & 3 & 0 & 0 & 0 & 0 & 0 & 39 \\
\hline G & 0 & 0 & 2 & 2 & 3 & 3 & 4 & 4 & 4 & 4 & 4 & 4 & 4 & 4 & 4 & 4 & 4 & 4 & 0 & 58 \\
\hline \multicolumn{21}{|c|}{ Lesion size } \\
\hline $\mathrm{R}$ & 0 & 1 & 0 & 1 & 1 & 1 & 1 & 1 & 1 & 1 & 1 & 1 & 1 & 1 & 0 & 0 & 0 & 0 & 0 & 12 \\
\hline G & 0 & 0 & 1 & 1 & 2 & 2 & 2 & 2 & 2 & 2 & 2 & 2 & 2 & 2 & 2 & 2 & 2 & 2 & 0 & 30 \\
\hline $\mathrm{R}$ & 0 & 1 & 0 & 1 & 2 & 2 & 2 & 2 & 2 & 2 & 2 & 2 & 2 & 1 & 0 & 0 & 0 & 0 & 0 & 21 \\
\hline G & 0 & 0 & 1 & 2 & 2 & 2 & 2 & 2 & 2 & 2 & 2 & 2 & 2 & 2 & 2 & 2 & 2 & 1 & 0 & 30 \\
\hline $\mathrm{R}$ & 0 & 0 & 0 & 0 & 0 & 0 & 0 & 0 & 0 & 0 & 0 & 0 & 0 & 0 & 0 & 0 & 0 & 0 & 0 & 0 \\
\hline G & 0 & 0 & 0 & 0 & 0 & 0 & 1 & 1 & 1 & 1 & 1 & 1 & 1 & 1 & 0 & 0 & 0 & 0 & 0 & 8 \\
\hline \multicolumn{21}{|c|}{ Total clinical score } \\
\hline $\mathrm{R}$ & 0 & 3 & 0 & 6 & 7 & 8 & 9 & 9 & 9 & 9 & 8 & 8 & 8 & 6 & 0 & 0 & 0 & 0 & 0 & 90 \\
\hline G & 0 & 0 & 5 & 8 & 11 & 11 & 13 & 13 & 14 & 14 & 14 & 14 & 13 & 11 & 8 & 8 & 8 & 7 & 0 & 172 \\
\hline
\end{tabular}

Table 3

Clinical scores applied to EHV-3 induced lesions observed in mares R, G (reinfection), A and M (primary infection) during the 2nd experiment.

\begin{tabular}{|c|c|c|c|c|c|c|c|c|c|c|c|c|c|c|c|c|c|c|c|c|}
\hline \multirow[t]{2}{*}{ Mares } & \multicolumn{20}{|c|}{ Days post-infection } \\
\hline & 0 & 1 & 2 & 3 & 4 & 5 & 6 & 7 & 8 & 9 & 10 & 11 & 12 & 13 & 14 & 15 & 16 & 17 & 18 & Total \\
\hline \multicolumn{21}{|c|}{ Tumefaction } \\
\hline $\mathrm{R}$ & 0 & 1 & 1 & 1 & 1 & 1 & 1 & 1 & 0 & 0 & 0 & 0 & 0 & 0 & 0 & 0 & 0 & 0 & 0 & 7 \\
\hline G & 0 & 0 & 0 & 0 & 0 & 0 & 0 & 0 & 0 & 0 & 0 & 0 & 0 & 0 & 0 & 0 & 0 & 0 & 0 & 0 \\
\hline A & 0 & 0 & 1 & 1 & 1 & 1 & 1 & 1 & 1 & 1 & 1 & 1 & 1 & 0 & 0 & 0 & 0 & 0 & 0 & 11 \\
\hline M & 0 & 0 & 0 & 1 & 1 & 1 & 1 & 1 & 1 & 1 & 1 & 1 & 1 & 0 & 0 & 0 & 0 & 0 & 0 & 10 \\
\hline \multicolumn{21}{|c|}{ Discharge } \\
\hline $\mathrm{R}$ & 0 & 2 & 2 & 0 & 0 & 0 & 0 & 0 & 0 & 0 & 0 & 0 & 0 & 0 & 0 & 0 & 0 & 0 & 0 & 4 \\
\hline G & 0 & 0 & 0 & 0 & 0 & 0 & 0 & 0 & 0 & 0 & 0 & 0 & 0 & 0 & 0 & 0 & 0 & 0 & 0 & 0 \\
\hline A & 0 & 0 & 0 & 1 & 0 & 2 & 2 & 2 & 3 & 3 & 3 & 3 & 1 & 0 & 0 & 0 & 0 & 0 & 0 & 20 \\
\hline M & 0 & 0 & 0 & 0 & 0 & 0 & 0 & 0 & 0 & 0 & 0 & 0 & 0 & 0 & 0 & 0 & 0 & 0 & 0 & 0 \\
\hline $\mathrm{R}$ & 0 & 0 & 0 & 0 & 0 & 0 & 0 & 0 & 0 & 0 & 0 & 0 & 0 & 0 & 0 & 0 & 0 & 0 & 0 & 0 \\
\hline G & 0 & 0 & 0 & 0 & 0 & 0 & 0 & 0 & 0 & 0 & 0 & 0 & 0 & 0 & 0 & 0 & 0 & 0 & 0 & 0 \\
\hline A & 0 & 0 & 0 & 0 & 1 & 1 & 1 & 1 & 1 & 1 & 0 & 0 & 0 & 0 & 0 & 0 & 0 & 0 & 0 & 6 \\
\hline M & 0 & 0 & 1 & 1 & 1 & 1 & 1 & 1 & 1 & 1 & 0 & 0 & 0 & 0 & 0 & 0 & 0 & 0 & 0 & 8 \\
\hline \multicolumn{21}{|c|}{ Lesion type } \\
\hline $\mathrm{R}$ & 0 & 0 & 0 & 0 & 0 & 0 & 1 & 1 & 4 & 4 & 4 & 4 & 4 & 4 & 0 & 0 & 0 & 0 & 0 & 26 \\
\hline G & 0 & 0 & 0 & 0 & 2 & 2 & 2 & 2 & 2 & 2 & 2 & 4 & 4 & 0 & 0 & 0 & 0 & 0 & 0 & 22 \\
\hline A & 0 & 0 & 2 & 2 & 2 & 4 & 4 & 4 & 4 & 4 & 4 & 4 & 4 & 4 & 4 & 4 & 4 & 4 & 0 & 58 \\
\hline M & 0 & 2 & 1 & 1 & 2 & 3 & 3 & 3 & 4 & 4 & 4 & 4 & 4 & 4 & 0 & 0 & 0 & 0 & 0 & 39 \\
\hline \multicolumn{21}{|c|}{ Lesion size } \\
\hline $\mathrm{R}$ & 0 & 0 & 0 & 0 & 0 & 0 & 1 & 1 & 1 & 1 & 1 & 1 & 1 & 1 & 0 & 0 & 0 & 0 & 0 & 8 \\
\hline G & 0 & 0 & 0 & 0 & 1 & 1 & 1 & 1 & 1 & 1 & 1 & 1 & 1 & 0 & 0 & 0 & 0 & 0 & 0 & 9 \\
\hline A & 0 & 0 & 1 & 1 & 1 & 2 & 2 & 2 & 2 & 2 & 2 & 2 & 2 & 2 & 2 & 2 & 2 & 1 & 0 & 28 \\
\hline $\mathrm{M}$ & 0 & 1 & 1 & 1 & 1 & 1 & 1 & 1 & 1 & 1 & 1 & 1 & 1 & 1 & 0 & 0 & 0 & 0 & 0 & 13 \\
\hline $\mathrm{R}$ & 0 & 0 & 0 & 0 & 0 & 0 & 1 & 1 & 1 & 1 & 1 & 1 & 1 & 1 & 0 & 0 & 0 & 0 & 0 & 8 \\
\hline G & 0 & 0 & 0 & 0 & 1 & 1 & 1 & 2 & 1 & 1 & 1 & 1 & 1 & 0 & 0 & 0 & 0 & 0 & 0 & 10 \\
\hline A & 0 & 0 & 1 & 1 & 2 & 2 & 2 & 2 & 2 & 2 & 2 & 2 & 2 & 2 & 2 & 2 & 2 & 1 & 0 & 29 \\
\hline $\mathrm{M}$ & 0 & 1 & 1 & 1 & 2 & 2 & 2 & 2 & 2 & 2 & 2 & 2 & 2 & 1 & 0 & 0 & 0 & 0 & 0 & 22 \\
\hline $\mathrm{R}$ & 0 & 0 & 0 & 0 & 0 & 0 & 0 & 0 & 0 & 0 & 0 & 0 & 0 & 0 & 0 & 0 & 0 & 0 & 0 & 0 \\
\hline G & 0 & 0 & 0 & 0 & 0 & 0 & 0 & 0 & 0 & 0 & 0 & 0 & 0 & 0 & 0 & 0 & 0 & 0 & 0 & 0 \\
\hline A & 0 & 0 & 0 & 0 & 0 & 0 & 1 & 1 & 1 & 1 & 1 & 1 & 1 & 1 & 0 & 0 & 0 & 0 & 0 & 8 \\
\hline M & 0 & 0 & 0 & 0 & 0 & 0 & 0 & 0 & 0 & 0 & 0 & 0 & 0 & 0 & 0 & 0 & 0 & 0 & 0 & 0 \\
\hline \multicolumn{21}{|c|}{ Total clinical score } \\
\hline $\mathrm{R}$ & 0 & 3 & 3 & 1 & 1 & 1 & 4 & 4 & 6 & 6 & 6 & 6 & 6 & 6 & 0 & 0 & 0 & 0 & 0 & 53 \\
\hline G & 0 & 0 & 0 & 0 & 4 & 4 & 4 & 5 & 4 & 4 & 4 & 6 & 6 & 0 & 0 & 0 & 0 & 0 & 0 & 41 \\
\hline A & 0 & 0 & 5 & 6 & 7 & 12 & 13 & 13 & 14 & 14 & 13 & 13 & 11 & 9 & 8 & 8 & 8 & 6 & 0 & 160 \\
\hline $\mathrm{M}$ & 0 & 4 & 4 & 5 & 7 & 8 & 8 & 8 & 9 & 9 & 8 & 8 & 8 & 6 & 0 & 0 & 0 & 0 & 0 & 92 \\
\hline
\end{tabular}



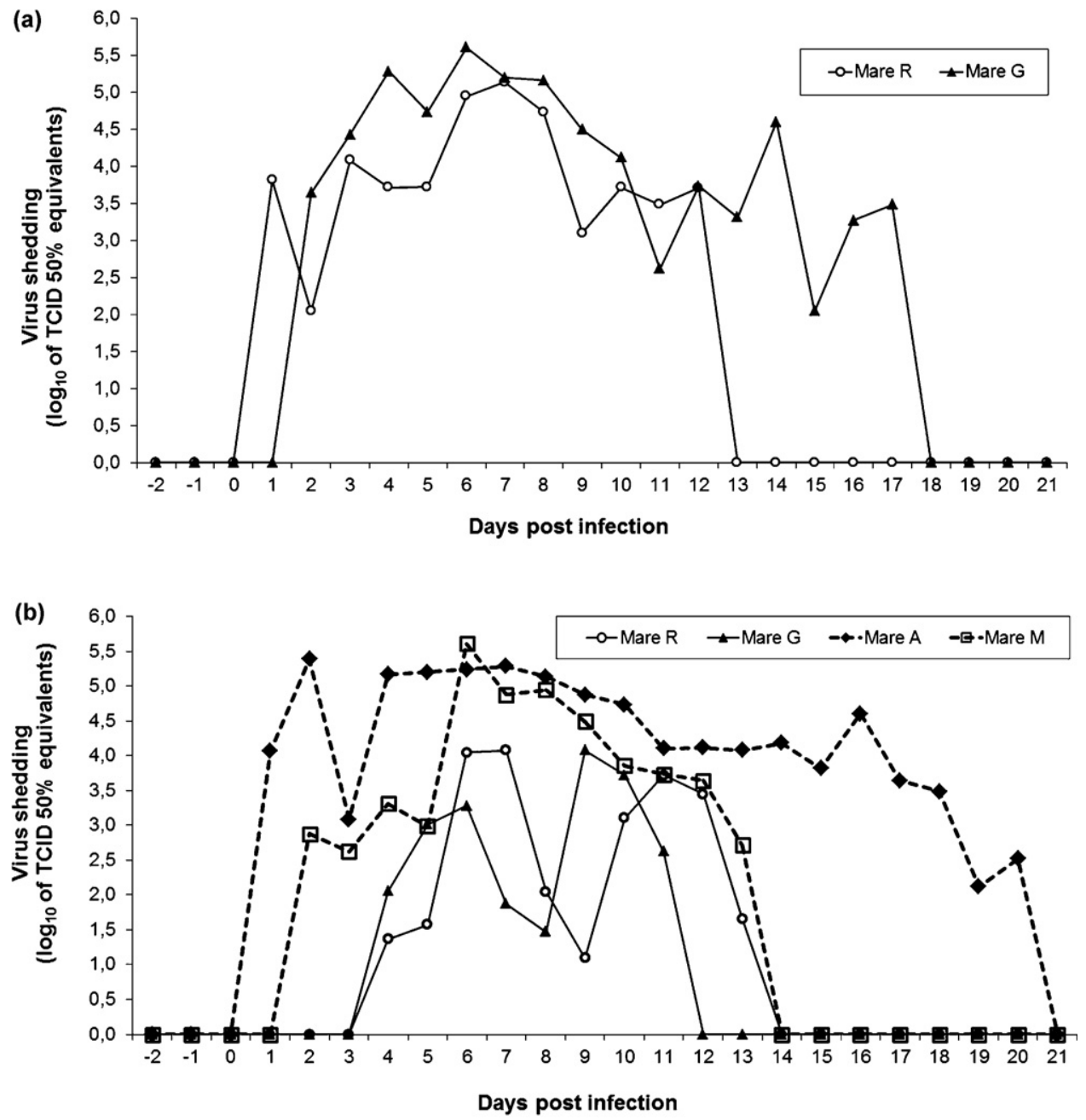

Fig. 2. Virus shedding after experimental challenge with EHV-3: (a) in seronegative mares R and G (primary infection/1st experiment), (b) in seronegative mares $\mathrm{A}$ and $\mathrm{M}$ (primary infection/2nd experiment) and seropositive mares $\mathrm{R}$ and $\mathrm{G}$ (re-infection/2nd experiment).

\begin{tabular}{|c|c|c|c|c|}
\hline First & $\mathrm{E} / 9283 / 07$ & 807 CCAGCTGCGGCAAAA 911 & 1096 CCTGCCGACGGAGAC 1110 & 1257 CAGAGTCGCCGAGCG 1271 \\
\hline experimental & Mare G & $807 \ldots \ldots \ldots 911$ & $1096 \ldots \ldots \ldots \ldots . \ldots 1110$ & $1257 \ldots \ldots \ldots \ldots \ldots 1271$ \\
\hline \multirow[t]{2}{*}{ infection } & Mare $\mathrm{R}$ & $807 \ldots \ldots \ldots 911$ & $1096 \ldots \ldots \ldots \ldots 1110$ & $1257 \ldots \ldots \ldots \ldots \ldots$ \\
\hline & $\mathrm{E} / 1333 / 07$ & 807 CCAGCTGAGGCAAAA 911 & 1096 CCTGCCGCCGGAGAC 1110 & 1257 CAGAGTCTCCGAGCG 1271 \\
\hline Second & Mare G & $807 \ldots \ldots \ldots \ldots 911$ & $1096 \ldots \ldots \ldots \ldots \ldots$ & $1257 \ldots \ldots \ldots \ldots \ldots$ \\
\hline experimental & Mare $\mathrm{R}$ & $807 \ldots \ldots \ldots 911$ & $1096 \ldots \ldots \ldots \ldots \ldots$ & $1257 \ldots \ldots \ldots \ldots \ldots$ \\
\hline \multirow[t]{2}{*}{ infection } & Mare A & $807 \ldots \ldots \ldots 911$ & $1096 \ldots \ldots \ldots \ldots 1110$ & $1257 \ldots \ldots \ldots \ldots \ldots$ \\
\hline & Mare $\mathrm{M}$ & $807 \ldots \ldots \ldots 911$ & $1096 \ldots \ldots \ldots \ldots \ldots$ & $1257 \ldots \ldots \ldots \ldots \ldots 1271$ \\
\hline
\end{tabular}

Fig. 3. Partial nucleotide sequence of gG gene of the EHV-3 used as inocula in the 1st (E/9283/07) and in 2nd experiment (E/1333/07) compared with the virus detected at the peak of shedding period from each mare.

\section{Discussion}

A topical experimental infection with EHV-3 was able to produce ECE clinical signs, which were closely similar to those previously described during field outbreaks (Barrandeguy, 2010; Tibary and Fite, 2007; Van der Meulen et al., 2006; Allen and Umphenour, 2004; Kleiboeker and
Chapman, 2004; Seki et al., 2004). This experimental model was even able to produce clinical signs and virus shedding in seropositive (previously infected) mares. Initial neutralizing antibody titres in mares $R$ and $G$ in the 2nd experiment evidence previous active specific immune response, which could contribute to the mitigation of clinical signs, as observed in those mares with respect to 
(a)

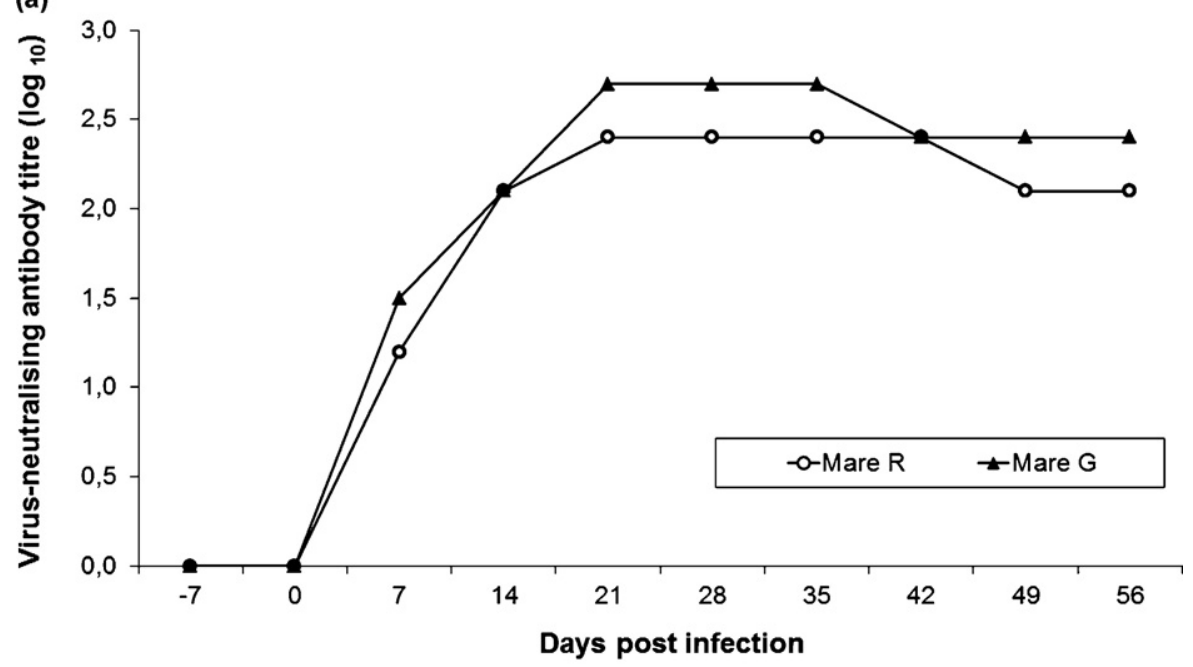

(b)

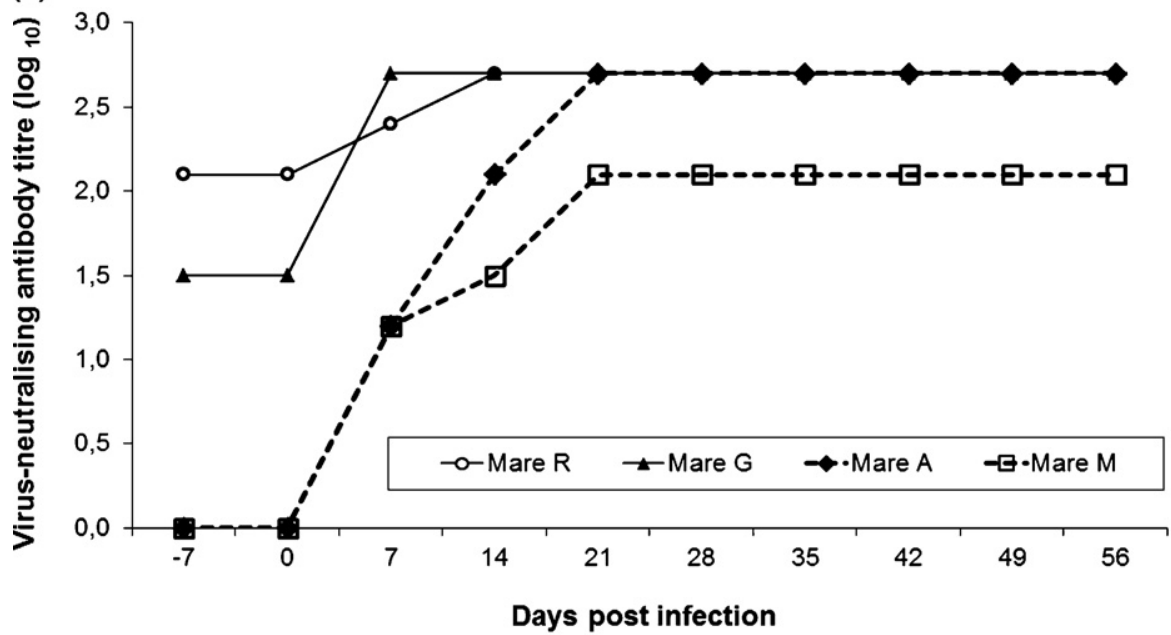

Fig. 4. Neutralizing antibody response after experimental infection with EHV-3: (a) in mares R and G (primary infection/1st experiment), (b) in mares A and $\mathrm{M}$ (primary infection/2nd experiment) and in mares R and G (re-infection/2nd experiment).

the seronegative ones. The immune mechanisms that control the EHV-3 infection are yet unknown, but mucosal and cell-mediated immune responses could also play a role as in other herpesvirus infections (Roizman et al., 2007). In a transmission experiment carried out by Krogsrud and Onstad (1971), a mare with increased neutralizing antibodies due to a natural clinical EHV-3 infection (which had taken place 4 months before the time of the experiment) did not show any ECE typical clinical signs. In our conditions, however, mild lesions were still observed. This may reflect differences in the level of the protective immune response between animals.

Like in other similar works (Dal Pozzo et al., 2009), the use of a scoring approach allowed us to appreciate the effects of infection in each individual, describe precisely the progression of the disease over time, and compare its consequences between the mares. The total clinical score of mare $G$ (first experiment) was highly similar to that of mare A (second experiment). These mares showed more severe ECE clinical signs than mares $\mathrm{R}$ (first experiment) and $\mathrm{M}$ (second experiment), all of them seronegative at the time of experimental infection. The variation of total clinical scores among seronegative mares (90, 92, 160 and 172 ) could not be associated with age, gestational status or other conditions. Allen and Umphenour (2004) described that the severity and duration of the disease vary considerably among individual horses; nevertheless, in uncomplicated cases, healing of the lesions is complete by 10-14 days. Regarding the seropositive mares, the total clinical scores (53 and 41) observed in R and G during the second experiment were similar between them. Virus shedding was detected in all mares, but differences in the duration (days) and intensity (virus load) were found, being 12, 16, 20 and 12 days (duration) and 10 $0^{5.50}$ (virus excretion titre at peak) in seronegative mares versus 10 and 8 days (duration) and $10^{4.00}$ (virus excretion titre at 
peak) in seropositive mares. The range of variation in clinical scores and virus excretion could be more precisely assessed by using a greater number of animals in further investigations.

The presence of discrete clinical signs (total clinical scores of mares $\mathrm{R}$ and $\mathrm{G}$ in the second experiment were 53 and 41 respectively) in seropositive mares reflects the effect of an immune response that was, however, insufficient to prevent re-infection and virus shedding.

Assuming that mares $\mathrm{G}$ and $\mathrm{R}$ were latently infected at the time of the second experimental topical challenge with EHV-3, the virus recovered post infection could have been the product of a reactivation process. In order to elucidate this point, the gG gene of the virus shed by each mare was sequenced, revealing that mares $G$ and $R$ were reinfected with EHV-3 at the time of second experimental challenge. This fact clearly demonstrates that reinfection is possible: mares which had been previously infected and presumably carried the virus as latent infection can suffer a new EHV-3 infection and shed virus to the environment. This point could be relevant in field conditions, as latently infected mares may not only reactivate the virus and shed it (Barrandeguy et al., 2010c), but also be reinfected and shed a second virus to other horses. The establishment of a latency stage with the second virus may also be hypothesized but needs to be demonstrated.

As previously reported, experimental infection had no effect on gestation (Van der Meulen et al., 2006; Allen and Umphenour, 2004). Mare $M$, which was pregnant at the beginning of the experiment, carried its pregnancy to term and delivered a clinically healthy foal 18 days post infection.

Topical inoculation of EHV-3, as carried out in this work, closely mimics the situation that can occur in natural exposure to the virus by coitus and also in the embryo transfer and artificial insemination practices (Allen and Umphenour, 2004; Barrandeguy et al., 2010a).

The accuracy and reproducibility of the experimental infection protocol described will be further evaluated by using a larger number of animals and equalizing the age of the mares as much as possible.

Although carried out in a small number of animals, the experimental protocol presented in this study consistently reproduced the lesions observed in natural outbreaks of ECE. It can thus be used to monitor the virus shedding patterns and neutralizing antibody kinetics, and could therefore be very useful for future EHV-3 research including antiviral therapy and other preventive or therapeutic measures.

\section{Acknowledgements}

This work was supported by the INTA HARAS Agreement and by a research collaboration agreement between FRSFNRS (Fonds de la Recherche Scientifique, Belgium) and CONICET (National Research Council of Argentina). Tissue culture, provided by Dr Osvaldo Zabal, and care of the mares and assistance on daily sampling, provided by Diego Franco and Claudio Fioroni, are gratefully recognized.

\section{References}

Allen, G., Umphenour, N., 2004. Equine coital exanthema. In: Coetzer, J.A.W., Tustin, R.C. (Eds.), Infectious Disease of Livestocks. Oxford Press, Cape Town, South Africa, pp. 860-867.

Anon., 2007. Comité Institucional para el Cuidado y Uso de Animales de Experimentación.,http://www.inta.gov.ar/cnia/cicvya/cicuae/cicuae.asp.

Anon., 1985. Council for international Organizations of Medical Sciences. International Guiding Principles for Biomedical Research Involving Animals., http://www.cioms.ch/frame_1985_texts_of_guidelines.htm.

Barrandeguy, M., 2010. Virological aspects and pathogenesis of natural and experimental equid herpesvirus 3 infection in horses. Thesis D/ 2010/0480/14, Presses de la Faculté de Médecine vétérinaire de l'Université de Liège, ISBN 978-2-930404-79-0. http://bictel.ulg.ac.be/ETD-db/collection/available/ULgetd-09242010-134744/.

Barrandeguy, M., Thiry, E., 2012. Equine coital exanthema and its potential economic implications for the equine industry. Vet. J. 91, 35-40.

Barrandeguy, M., VissanI, A., Olguin, C., Miño, S., Pereda, A., Oriol, J., Thiry, E., 2008. Experimental reactivation of equine herpesvirus-3 following corticosteroid treatment. Equine Vet. J. 40, 593-595.

Barrandeguy, M., Perkins, J., Mac Donough, J., Vissani, A., Olguin Perglione, C., Thiry, E., 2010a. Occurrence of equine coital exanthema in mares from an embryo transfer center. J. Equine Vet. Sci. 30, 145-149.

Barrandeguy, M., Ulloa, N., Bok, K., Fernandez, F., 2010b. Outbreak of rhinitis caused by equid herpesvirus 3 . Vet. Rec. 166, 178.

Barrandeguy, M., Vissani, A., Pont Lezica, F., Salamone, J., Heguy, A., Becerra, L., Olguín Perglione, C., Thiry, E., 2010c. Subclinical infection and periodic shedding of equid herpesvirus 3. Theriogenology 74 , 576-580.

Blanchard, T., Kenney, R., Timoney, P., 1992. Venereal diseases. Vet. Clin. North Am. Equine Pract. 8, 191-203.

Burki, F., Lorin, D., Sibalin, M., Ruttner, O., Arbeiter, K., 1974. Experimental genital and nasal infection of horses with the equine coital exanthema virus. Zentralbl. Veterinärmed. Reihe B 21, 362-375.

Dal Pozzo, F., De Clercq, C., Guyot, H., Vandemeulebroucke, E., Sarradin, P., Vandenbussche, F., Thiry, E., Saegerman, C., 2009. Experimental reproduction of bluetongue virus serotype 8 clinical disease in calves. Vet. Microbiol. 136, 352-358.

Dynon, K., Varrasso, A., Ficorilli, N., Holloway, S., Reubel, G., Li, F., Hartley, C., Studdert, M., Drummer, H., 2001. Identification of equine herpesvirus 3 (equine coital exanthema virus), equine gammaherpesvirus 2 and 5, equine adenoviruses 1 and 2, equine arteritis virus and equine rhinitis A virus by polymerase chain reaction. Aust. Vet. J. 79, 695-702.

Girard, A., Greig, A.S., Mitchell, D., 1968. A virus associated with vulvitis and balanitis in the horse-a preliminary report. Can. J. Comp. Med. 32, 603-604.

Hall, T.A., 1999. BioEdit: a user-friendly biological sequence alignment editor and analysis program for Windows 95/98/NT. Nucleic Acids Symp. Ser. 41, 95-98.

Heuschele, W., Castro, A., 1992. Viral diagnosis: general considerations. In: Veterinary Diagnostic Virology, A Practitioner's Guide, Mosby Year Book, Section I, pp. 1-16.

Kleiboeker, S., Chapman, R., 2004. Detection of equine herpesvirus 3 in skin lesions by polymerase chain reaction. J. Vet. Diagn. Invest. 16, 74-79.

Krogsrud, J., Onstad, O., 1971. Equine coital exanthema. Isolation of a virus and transmission experiments. Acta Vet. Scand. 12, 1-14.

Monteverde, J., Garbers, G., De Carlo, J., 1960. Exantema coital en yeguas S. P. C. Rev. Facul. Cien. Veterinarias de La Plata 4, 37-38.

Seki, Y., Seimiya, M., Yaegashi, G., Kumagai, S., Sentsui, H., Nishimori, T., Ishihara, R., 2004. Occurrence of equine coital exanthema in pastured draft horses and isolation of equine herpesvirus 3 from progenital lesions. J. Vet. Med. Sci. 66, 1503-1508.

Roizman, B., Knipe, D., Whitley, R., 2007. Herpes simplex viruses. In: Knipe, D., Howley, P., Griffin, D., Lamb, R., Martin, M., Roizman, B., Straus, S. (Eds.), Field Virology. Fifth Edition. Lippincott Williams \& Wilkins, Philadelphia, USA, pp. 2502-2553.

Tibary, A., Fite, C., 2007. Equine coital exanthema. In: Sellon, D., Long, M. (Eds.), Equine Infectious Diseases. Reproductive Tract Infections. Elsevier, PA, USA, (Chapter 8), p. 101.

Van der Meulen, K., Caij, A., Smets, K., Nauwynck, H., 2006. Equine coital exanthema in a mare in Belgium. Vl Diergeneeskd. Tijdschr. 75, 286-289. 